\title{
New Species of Siparuna (Siparunaceae) III. Three New Species and One Newly Ranked Entity from Colombia, Ecuador, and Peru
}

\author{
Susanne S. Renner \\ Department of Biology, University of Missouri-St. Louis, 8001 Natural Bridge Rd., \\ St. Louis, Missouri 63121, U.S.A., and Missouri Botanical Garden, \\ St. Louis, Missouri 63166, U.S.A.
}

Gerlinde Hausner

Werner-Hilpert-Str. 67, D-65197 Wiesbaden, Germany

Aвsткаст. Three new species of Siparuna (Siparunaceae) are described, illustrated, and placed in a phylogenetic context: $S$. gentryana from western Ecuador and adjacent Colombia, S. lozaniana from the western Andes in Colombia, and S. vasqueziana from Amazonian Peru. In addition, Siparuna calantha from the Sierra Nevada de Santa Marta, originally described by Janet Perkins as a variety of a Mexican entity, is raised to species rank because its broader leaves and more numerous carpels readily distinguish it from its apparent closest relative, a species from the western Colombian Andes. Each of the species is known from several collections, which allowed the secure matching of sexual morphs in the three that are dioecious.

Visits by the first author to major Colombian herbaria (COAH, COL, CUVC, HUA, JAUM, MEDEL, TULV, UDBC, and VALLE) in 1997 and 1999 brought to light abundant material of several previously undescribed species of Siparuna, a genus that we are monographing (Renner \& Hausner, 1995, 1996, 1997). Three of the species are now known from flowering and fruiting collections. However, we are still awaiting fully fruiting material of S. vasqueziana. Siparuna vasqueziana is unique in the genus in its flower size and morphology and can therefore be keyed out easily even in the absence of mature fruits.

The Siparunaceae are a distinct lineage of Laurales (Renner, 1999), the sister group of which are the Gomortegaceae from Chile (one species) and the Atherospermataceae from Chile and Australia, New Zealand, Tasmania, New Caledonia, and New Guinea (14 species). Siparunaceae are thus only distantly related to Monimiaceae sensu stricto, which are closest to Lauraceae and Hernandiaceae (Renner \& Chanderbali, in press). Siparunaceae consist of Siparuna (including Bracteanthus Ducke) and its sister group Glossocalyx, a monotypic West
African genus of dioecious straggling shrubs (Renner, unpublished obs.), very similar to Siparuna. Siparuna comprises 15 monoecious and at least 50 dioecious species. Ongoing molecular phylogenetic work in the genus (Renner \& Won, in prep.) indi(ates that the dioecious species form a single derived clade, while the monoecious clades are more basal and form more than one clade. Of the species described here, three are dioecious, while one, $S$. gentryana, is monoecious; none have been sequenced.

Although a few papers now exist on the pollination and floral function of Siparuna (Feil, 1992; Renner et al., 1997), we still have considerable work ahead of us before fully understanding the evolution of Siparunaceae floral morphology and breeding systems. We would be extremely indebted to anyone who would send us liquid-preserved flowers and/or leaves dried in silica gel to be used in ongoing anatomical and phylogenetic studies. Additionally, some nine suspected new species from Panama, Colombia, Ecuador, and Peru await the collection of flowers of both sexes before they can be described, and we would be happy to supply details to botanists collecting in these countries.

Siparuna gentryana Renner, sp. nov. TYPE: Ecuador. Carchi: Tulcán, Reserva Etnica Awá, Parroquia El Chical, Centro Gualpí Medio, Río Canumbí, 1150 m, 19-28 Feb. 1993, A. Grijalva, C. Aulestia \& J. Taicuz 606 (holotype, QCNE; isotypes, AAU, MO, NY, QCA, QCNE). Figures 1, 2, and 3.

A Siparuna cristata (Poeppig \& Endlicher) A. DC. fructibus minoribus tuberculatibusque differt.

Monoecious tree, 4-20 $\mathrm{m}$ tall and reaching a DBH of at least $34 \mathrm{~cm}$, branchlets terete but flattened at the nodes, densely grayish brown puberulous or glabrous. Leaves opposite, the petioles 1-

Novon 10: 134-143. 2000. 


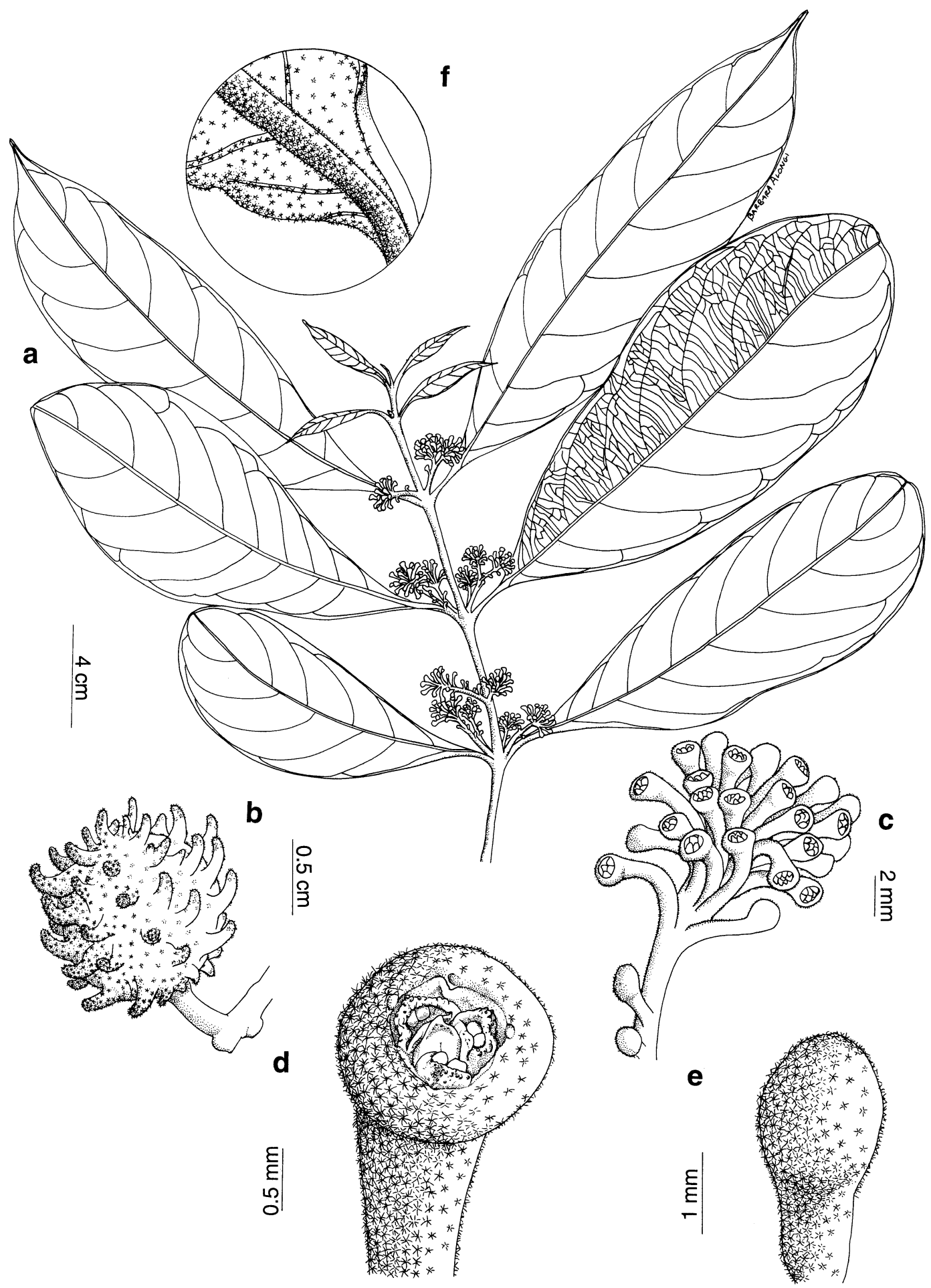

Figure 1. Siparuna gentryana Renner, drawn from representative paratypes. -a. Flowering specimen (Gentry et al. 53606, MO). — b. Fruit (Monsalve B. 1678, MO). —c. Inflorescence (Tipaz 2491, MO). —d. Male flower. —e. Bud. -f. Lower leaf surface indumentum. 

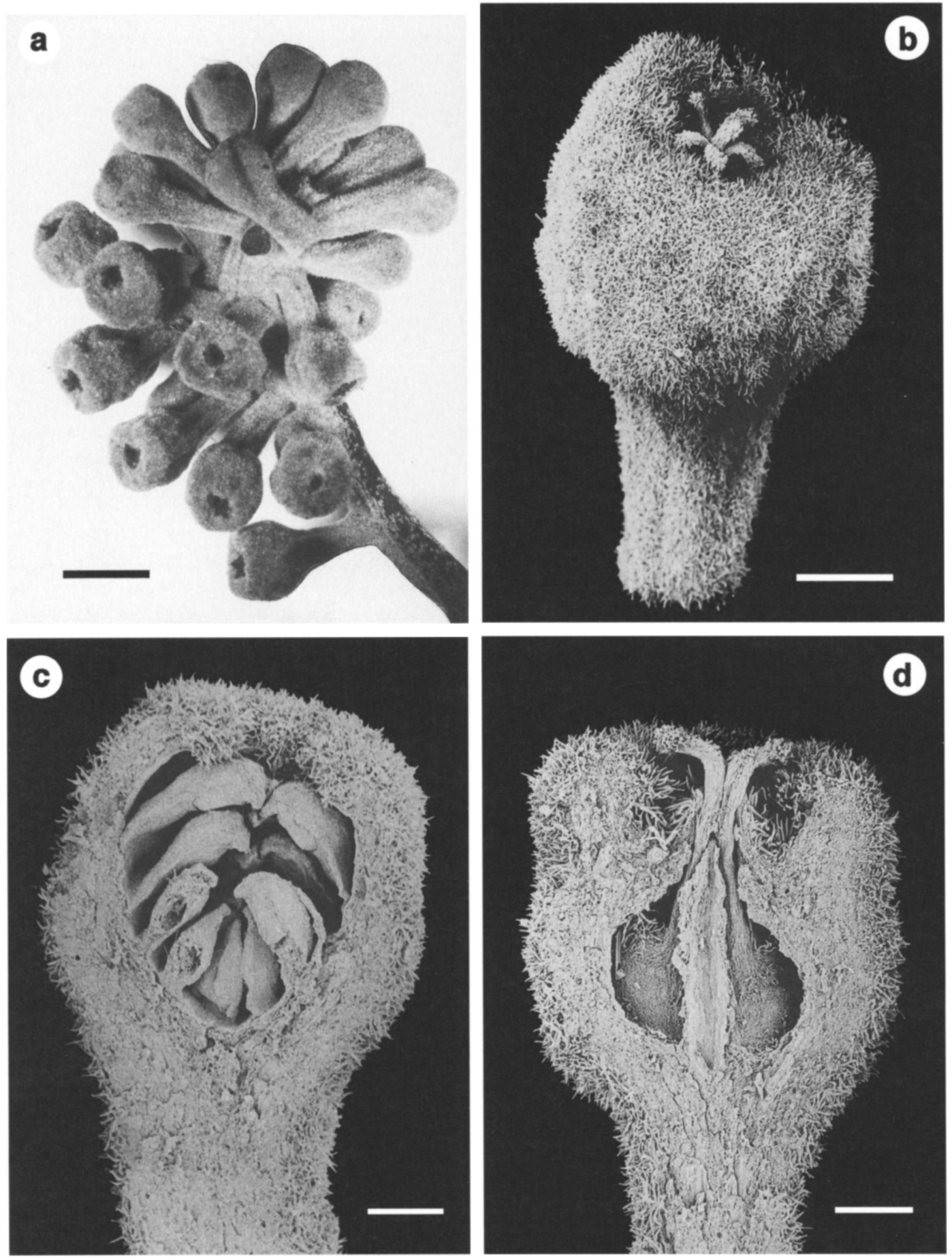

Figure 2. Siparuna gentryana Renner (Grijalva et al. 606, MO). - a. Inflorescence; female flowers on the left with exserted styles (scale bar equals $2 \mathrm{~mm}$ ). b-d. Scanning electron micrographs. - b. Mature female flower (scale bar equals $0.5 \mathrm{~mm}$ ). $-\mathrm{c}$. Longitudinal section through a male flower, the pollen-sac valves still closed (scale bar equals $0.3 \mathrm{~mm}$ ). - d. Longitudinal section through a female flower, showing two carpels, their styles, and the floral roof, which tightly sheaths the styles where they emerge from the flower (scale bar equals $0.3 \mathrm{~mm}$ ). 


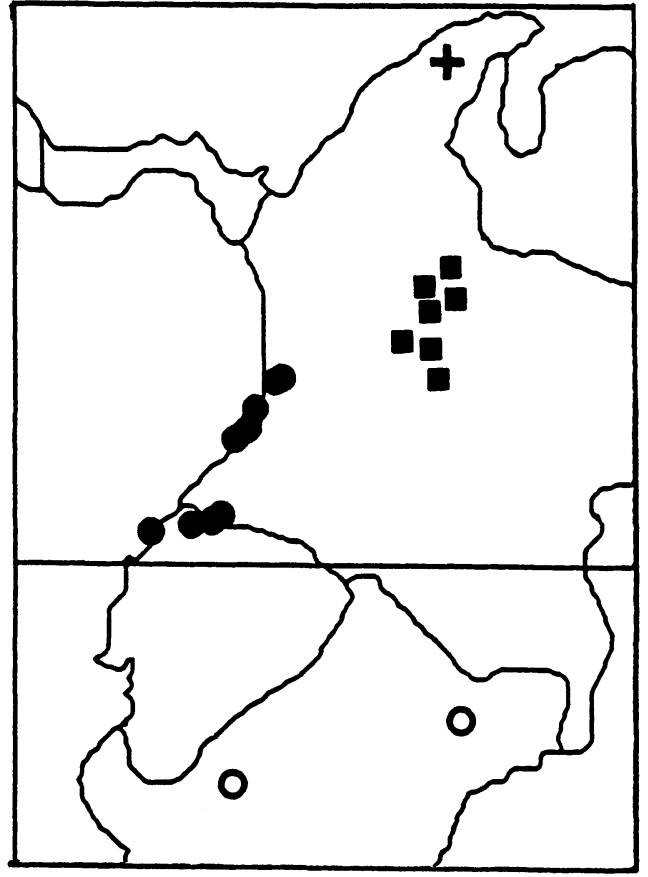

Figure 3. Distributions of Siparuna gentryana (closed circles), S. calantha (cross), S. vasqueziana (open circles), and $S$. lozaniana (squares) in northwestern South America.

$1.8(-3) \mathrm{cm}$ long, the lamina drying dark reddish brown or rarely pale green, stiff-chartaceous to leathery, oblong, $20-35(-40) \times(8-) 10-15 \mathrm{~cm}$, the base acute to obtuse, the apex cuspidate, the tip to $1 \mathrm{~cm}$ long, lamina above and below glabrous except for the midrib, which may be minutely puberulous near the petiole, with 6 to 13 pairs of secondary veins, flat above, slightly raised below, the margin entire. Cymes 2-3 cm long, short-branched (Figs. 1c, 2a) and mostly borne in pairs in the leaf axils as is characteristic of the genus, with 15 to 20 flowers, the pedicels $2-4 \mathrm{~mm}$ long and densely puberulous. Male flowers at anthesis 1.5-2.2 mm diam., subglobose in shape, the receptacle as puberulous as the cymes, the 5 tepals fused to a thick rim, when fresh cream, the floral roof a barely visible membranous rim within the tepal rim (Figs. 1d, 2c); stamens (5)9 to 20(30). Female flowers closely resembling the male flowers except that the floral roof forms a short cylinder tightly sheathing the styles (Fig. 2b, d); styles usually 5 (Fig. 2b). Fruiting receptacle $1.5(-2) \mathrm{cm}$ diam. and conspicuously tuberculate (Fig. 1b), the tubercles fleshy and up to $4 \mathrm{~mm}$ long; mature fruits purple or red, drying brown or black; drupelets 1 to 4 .

Distribution (Fig. 3), habitat, and phenology. Siparuna gentryana occurs in western Ecua- dor and Colombia (primarily in the Chocó phytogeographical region) in primary forests from sea level to $1150 \mathrm{~m}$. In Colombia, it has also been collected in Cauca and Valle, but not yet in Nariño where it probably occurs as well. Several sterile specimens from the department of Chocó are suspected to represent $S$. gentryana, but cannot be distinguished with confidence from $S$. cristata (see discussion below). Flowering and/or fruiting material has been collected in every month of the year.

Etymology. The species is named for the late Al Gentry who, during inventory work in the Chocó region, collected it at least nine times.

Common name. Comida de mono (Ecuador; indicating possible seed dispersal by primates).

Siparuna gentryana resembles $S$. cristata (Poeppig \& Endlicher) A. DC. in leaf shape and venation, but that species has smooth fruits that reach $3.5-4 \mathrm{~cm}$ in length, whereas $S$. gentryana fruits are tuberculate or spiny and only half that size. In $S$. cristata, pedicels of the male flowers often elongate during flowering, becoming up to $2 \mathrm{~cm}$ long, a character not seen in $S$. gentryana, where pedicels remain relatively short. Inflorescences and young branchlets in $S$. gentryana often have a puberulous indumentum (Fig. 2a-d) that is not seen in S. cristata. Siparuna cristata occurs throughout the Amazon basin and reaches northern Venezuela, adjacent northernmost Colombia, and Panama; its range therefore overlaps with that of $S$. gentryana in the Chocó.

Paratypes. COLOMBIA. Valle: Bajo Calima, $20 \mathrm{~m}$, 28 June 1961, Cabrera 559 (F); Mpio. Buenaventura, Quebrada San Joaquín, 100 m, 7 May 1968, Idrobo \& Garzón 6208 (COL); ca. $15 \mathrm{~km} \mathrm{~N}$ of Buenaventura, $50 \mathrm{~m}$, transect 9, 14 Feb. 1983, Gentry et al. 40208 (COL, JAUM, MO), transect 9, 15 Feb. 1983, Gentry et al. 40280 (COL, JAUM, MO), 26 Mar. 1986, Gentry et al. 53606 (MO), ca. $20 \mathrm{~km} \mathrm{~N}$ of Buenaventura, 12 Apr. 1987, Gentry et al. 56802 (CUVC, MO); Concesión Pulpapel Buenaventura, 100 m, 13 Dec. 1984, Monsalve B. 610 (COL, JAUM, MO), 3 June 1987, Monsalve B. 1508 (MO), 20 Aug. 1987, Monsalve B. 1646 (MO), I Sep. 1987, Monsalve B. 1678 (MO), 16 Oct. 1987, Monsalve B. 1973 (MO), 1 Aug. 1989, Monsalve B. 3141 (CUVC, MO), 26 May 1987, Faber-Langendoen et al. 654 (CUVC, MO), 4 July 1987, Faber-Langendoen 1157 (MO); Mpio. Buenaventura, Correg. Bajo Calima, Vda. San Isidro, 30 m, 17 May 1989, Daly et al. 6019 (CUVC, HUA, MO); Costa del Pacífico, Río Micay, en Guayabal, 5 m, 25 Feb. 1943, Cuatrecasas 14126 (F, VALLE). Cauca: Mpio. Guapí, Parq. Nac. de Isla Gorgona, 250 m, 16 Mar. 1975, Cabrera R. \& Rangel 3260 (CUVC), 1 June 1986, Lozano C. \& Rangel 5096 (COL); Costa del Pacífico, Río Naya, Correg. Puerto Merizalde, 15 m, 21 Feb. 1943, Cuatrecasas 14024 (US, VALLE). ECUADOR. Esmeraldas: Lita to San Lorenzo, km 25, near Alto Tambo, $740 \mathrm{~m}, 19$ July 1988, Dodson \& Gentry 17529 (MO, QCNE); Fila de Bilsa, 7 km E of San Jose de Bilsa, ca. $80 \mathrm{~km}$ due SW of Esmeraldas, $12 \mathrm{~km}$ 
SE of El Salto on Atacames-Muisne rd., transect 1, 280 m, 28 Jan. 1991, Gentry \& Josse 72777 (MO, QCNE); Eloy Alfaro, Reserva Ecológica Cotacachi Cayapas, San Miguel, $130 \mathrm{~m}, 15 \mathrm{Jan}$ 1993, Tipaz 2491 (AAU, MO, NY, QCNE), Tipaz 2633 (MO, QCNE), Tipaz 2644 (MO, QCNE).

Siparuna lozaniana Renner \& Hausner, sp. nov. TYPE. Colombia. Cundinamarca: $12 \mathrm{~km}$ SE of Gachalá, 2440 m, female specimen, 21 Sep. 1944, M. L. Grant 10213 (holotype, COL; isotypes, NA, NY, US, WIS). Figures 4 and 3.

A Siparuna petiolaris (Kunth, in Humboldt \& Bonpland) A. DC. fructibus vix tuberculatibus differt.

Dioecious shrub or treelet, 1-8 (rarely to 16) $\mathrm{m}$ tall, young branchlets subangular or terete, subglabrous or sparsely stellate-pubescent. Leaves in whorls of 3 or opposite, the petioles $0.7-5 \mathrm{~cm}$ long, the lamina drying reddish brown, oblanceolate to obovate, rarely broadly elliptic, 8-14(-26.5) $\times$ $2.7-5(-11) \mathrm{cm}$, the base acute to obtuse, the apex acute to obtuse, the tip $0.5-0.8 \mathrm{~cm}$ long, leaves above and below with few minute appressed stellate to sublepidote hairs, occasionally glabrescent, young leaves above sometimes with conspicuous appressed silvery stellate-lepidote hairs, with 9 to 12 pairs of secondary veins, these flat above, distinctly raised below, the margin serrulate or serrate. Cymes 2.5-4 cm long and often pendent, with 10 to 15 flowers, pubescent like the young branchlets. Male floral cup at anthesis $2.0-2.9 \mathrm{~mm}$ diam. and $1.5-2.5 \mathrm{~mm}$ high, broadly obconical to semiglobose, glabrous except for a few appressed bifid or fewbranched hairs, tepals 4 or 5(6), narrowly triangular to almost spatulate (Fig. $4 \mathrm{~b}$ ), 2-4 mm long, fresh greenish yellow or whitish, the floral roof distinctly raised, and glabrous; stamens 9 to 12 . Female floral cup at anthesis $3.5-4 \mathrm{~mm}$ diam. and $3-3.5 \mathrm{~mm}$ high, subglobose, the pubescence as in the male flowers, the floral roof raised to a cylindrical bulge separated by a groove from an acute central tube sheathing the styles (Fig. 4f), drying dark brown; styles 2 to 5 . Fruiting receptacle $1-1.5 \mathrm{~cm}$ diam., globose and basally usually with minute (less than $1 \mathrm{~mm}$ long) protuberances (Fig. 4e); when fresh and mature red with cream spots (lenticels) and a strong lemon smell; drupelets 1 to 3 .

Distribution (Fig. 3), habitat, and phenology. Siparuna lozaniana is restricted to the eastern
Andean cordillera in central Colombia where it appears common in the states of Santander, Boyacá, and Cundinamarca. Growing in wet montane forest, in páramo and subpáramo at $1600-3300 \mathrm{~m}$ elevation. Flowering and fruiting collections have been made throughout the year.

Etymology The species is named in honor of Gustavo Lozano C., curator at the Colombian National herbarium (COL) and professor at the Colombian National University, who was among the first to collect it.

Common name. Limoncillo.

Siparuna lozaniana is easily recognized among Colombian species by the combination of oblanceolate to obovate leathery leaves, pendent inflorescences with a sparse indumentum of appressed few-branched hairs, and small globose fruits. Other Colombian species that sometimes have similar leaves are $S$. petiolaris from the western Andean Cordillera and S. calantha (described below) from the Sierra Nevada de Santa Marta. Both differ from $S$. lozaniana in having distinctly spiny or spinytuberculate fruits.

Paratypes. C(OLOMBIA. Boyacá: between Sogamoso and Pajarito, $\mathrm{km}$ 80, 25.50 m. i0 Mar. 1980, Bernal-M. 341 (COL). 10 Mar. 1980, Bernal-M. 376 (COI): vice of Areabuco, $2600 \mathrm{~m}, 290$ (O). 196:3, Espinal-T. \& Montenegro-M. I412 (COI); Mpio. Arcabuco, V da. Peñas Blan(as, Hac. Las Delicias, $2600 \mathrm{~m}, 10$ Mar. 1996. FernandezA. et al. 14112 (COL); Arcabuco, towards sítio La Cumbre, $2300 \mathrm{~m}, 22$ May 1979, Valencia \& Jeréz-F. I6 (COL); below Vadohondo, $\mathrm{km} 302$. sítio La Sabana, $2000 \mathrm{~m}, 24$ Feb. 1954. Idrobo \& Jaramillo-Mejía 1577 (COL); Mpio. Pajarito, Correg. de Corinto, 2200 m, 11 Oct. 1967, Lozano C. et al. 859 (COL); entre Moniquirá and Cachantivá, $2000 \mathrm{~m}, 14$ May 1996, Rangel et al. 13238 (COL). Cundinamarea: Mpio. Junín, Correg. Inspecciones Chuscales, Res. Biol. Carpanta, 2500-3300 m, 27 Apr. 1988, Luteyn et al. 12203 (F, NY); Chingaza National Park, Cordillera (Oriental E of Bogotá, 2800)-3000 m, 30 Oct. 1992, Gentry \& Repizzo 78067 (MO); Carpanta Biological Reserve, $20 \mathrm{~km}$ due W of Junín, 2400-3000 m, 1990, Repizzo \& Calle 167 (MO); Mpio. Chingaza, Goitia 1962 (UDBC), Goitia 1964 (UDBC). Meta: Mpio. El Calvario, Finca San Luís, 2250 m, 4 Mar. 1981, Camargo-(G. \& Huertas-G. 7875 (COL). Santander: border to Boyacá, Correg. Virolín, Finca La Sierra, 2500 m, 13 May 1976, Lozano C. et al. 2429 (COL); Mpio. Charalá, Vda. El Taladro, km 50-55 of rd. from Duitama to Virolín, $2280 \mathrm{~m}$, 6 Dec. 1978, Díaz-P. 1635 (COL); Mpio. Charalá, Correg. Virolín, near Río de la Pescada, 1830 m, 13 May 1982, Valbuena \& Harker 038 (COL); Mpio. Charalá, Correg. Virolín, rd. to Olival, Vda. Reloj, 1700 m, 3 Mar. 1981, Díaz-P. 2270 (COL); Correg. Virolín, $2180 \mathrm{~m}$, Escobar et

Figure 4. Siparuna lozaniana Renner \& Hausner (Camargo-G. \& Huertas-G. 7875, COL, except where indicated). a. Female specimen. - b. Male flower (Rangel 2171, COL). —c. Longitudinal section through a male flower (Diaz-P. $2270, \mathrm{COL}) .-\mathrm{d}$. Male inflorescence (Rangel 2171, COL). - e. Young fruit with minute tubercles near the base. - $\mathrm{f}$. Female flower. -g. Leaf venation. - h. Male inflorescences (Rangel 2171, COL). Drawn from representative paratypes. 


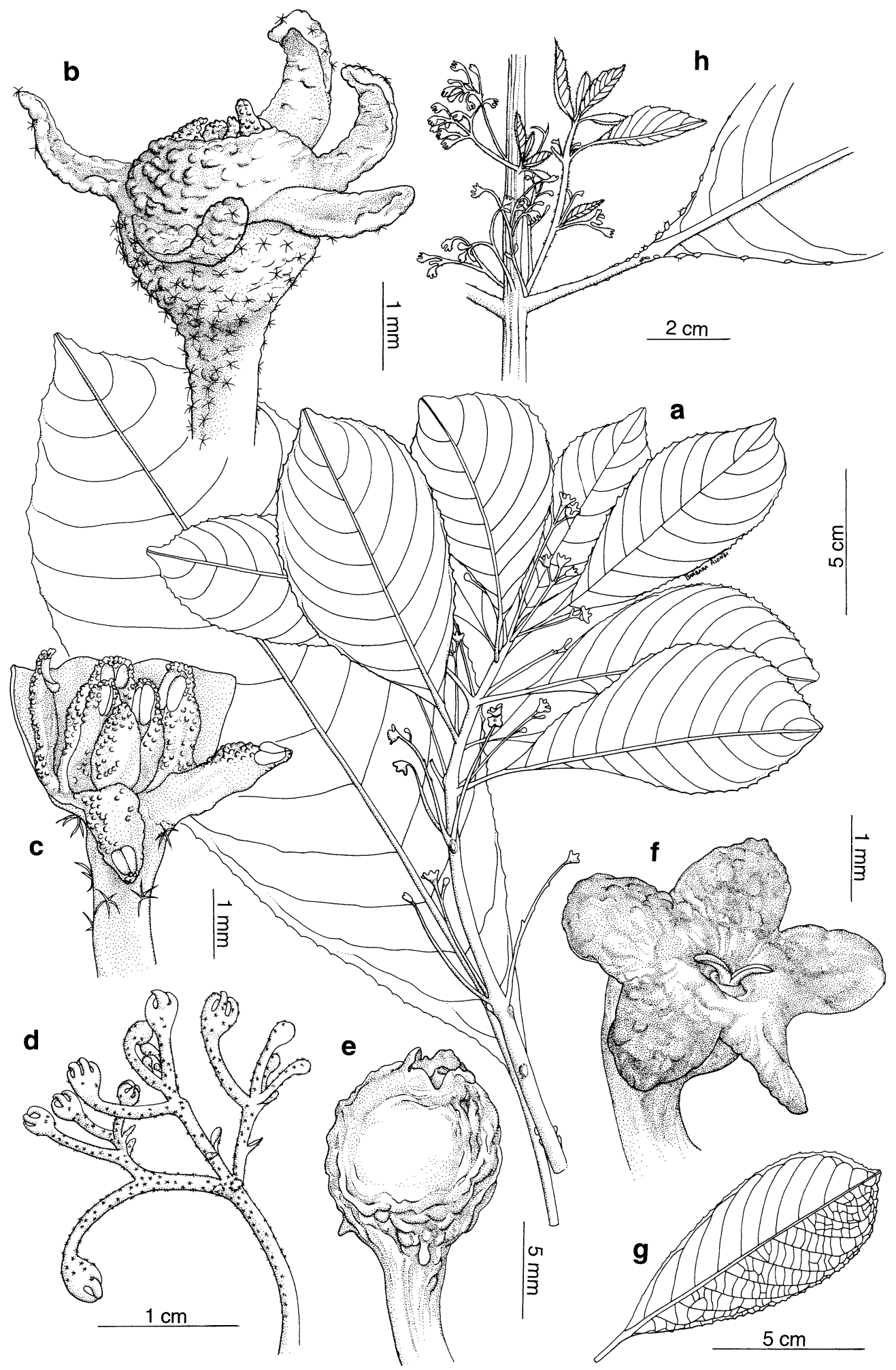


al. 3072 (HUA); Mpio. Charalá, $2180 \mathrm{~m}, 8$ May 1986 Moreno \& Méndez 78 (COL); Charalá, 1990 m, 20 Aug. 1979, Rangel 2171 (COL, U. US); Mpio. Gámbita, Vda. El Taladro, $2150 \mathrm{~m}, 13$ Nov. 1981, Camacho et al. 92 (COL), Orozco 1018 (COL); vic. of Bogotacito, 1800 m, 27 Nov. 1978, Diaz-P. 1204 (COL); rd. Arcabuco to La Palma, 3 July 1971, Guarín M. \& Villarreal 1070 (UPTC).

Siparuna calantha (Perkins) Renner \& Hausner, stat. nov. Basionym: Siparuna riparia var. calantha Perkins, Notizbl. Bot. Gart. Berlin-Dahlem 10: 164. 1927. TYPE. Colombia. Magdalena: Sierra Nevada de Santa Marta, Las Nubes, ca. $1500 \mathrm{~m}$, male specimen, Dec. 1898, H. H. Smith 847 (holotype, B destroyed; isotypes, BM, BR, COL, E, F, G, GH, K, L, LE, LL, MO, NY, P 3 sheets, S, U, UC, US). Figures 3 and 5 .

Dioecious shrub or treelet, 1-10 $\mathrm{m}$ tall and reaching a DBH of at least $7 \mathrm{~cm}$, the young branchlets distinctly angular, densely brown puberulous or pilose. Leaves in whorls of 3 , often unequal in size and petiole length, the petioles 2-9 cm long, the lamina drying dark brown, papery to chartaceous, obovate, $16.5-27 \times 7.5-15.5 \mathrm{~cm}$, the base acute, obtuse, or almost rounded, the apex acute or acuminate, the tip to $1.3 \mathrm{~cm}$ long, both surfaces loosely covered with small appressed or upright stellate hairs especially along the midrib, with 12 to 18 pairs of secondary veins, these flat above, distinctly raised below, the margin doubly serrate or dentate. Cymes 2-4 cm long, with 10 to 15 flowers, sparsely pubescent with spreading fewbranched hairs. Male floral cup at anthesis 2.5-3.5 $\mathrm{mm}$ diam. and $2-2.5 \mathrm{~mm}$ high, broadly obconical, tepals mostly 5 , broadly triangular, when fresh yellowish green, turning yellow, the floral roof moderately raised, glabrous and membranaceous; stamens 20 to 22 , the filaments broad and membranaceous. Female flowers at anthesis similar to the male flowers, the floral roof slightly raised and glabrous; styles 5 to 8 . Fruiting receptacle globose, $1-1.5 \mathrm{~cm}$ diam., with conspicuous protuberances 1-7 mm long, these either simple or flat and branched, soft when fresh (Fig. 5), fruit and tubercles with few minute stellate hairs; when fresh and mature whitish, cream or yellow, strongly lemonscented or with a pungent odor; drupelets 2 to 5 .

Distribution (Fig. 3), habitat, and phenology. Siparuna calantha is endemic on the Sierra Nevada de Santa Marta, where it occurs in upper montane forest at elevations between 1200 and $2000 \mathrm{~m}$. Flowering and fruiting collections have been made in most months of the year.

The type of Siparuna riparia var. calantha Per- kins, H. H. Smith 847, is a male plant, and Perkins therefore could not have known that female plants of this entity would have spiny fruits. A female plant had in fact been collected by Smith $(H$. $H$. Smith 2508) a few months earlier also on the Sierra de Santa Marta, but unfortunately Perkins appears not to have received it on loan. She initially identified Smith 847 as "S. patelliformis?" (a Central American synonym of $S$. gesnerioides) but later described it as a variety of the Mexican $S$. riparia (a synonym of $S$. thecaphora), apparently in an attempt to accommodate the deeply serrate leaf margins of the Sierra Nevada material. The type of S. riparia, Galeotti 269 (BR 3 sheets, G, K 2 sheets, LE, P 3 sheets, W destr., Machr. photo 30014), is indeed one of few specimens of $S$. thecaphora that have distinct leaf teeth. Even so, Perkins's assignment of Smith 847 to $S$. riparia remains problematic, because the leaves of $S$. calantha are about three times the size of those of the type of $S$. riparia, not to mention the implied Veracruz-Santa Marta disjunction.

The Sierra Nevada de Santa Marta, a geographically isolated mountain range, is known to harbor many locally adapted, morphologically distinct forms, and we therefore prefer to recognize $S$. calantha at the species level, rather than ranking it as a subspecies of the morphologically similar $S$. petiolaris from Antioquia, Quindío, and Valle. The two species resemble each other in the spiny fruiting receptacles and serrate leaf margin, hut differ in leaf width ( $S$. petiolaris has narrow, lanceolate leaves and $S$. calantha relatively broad, obovate ones) and number of carpels (5 to 8 in S. calantha vs. 3(4) in $S$. petiolaris). Fruiting receptacles in $S$. petiolaris measure $0.6-1 \mathrm{~cm}$ in diameter, while those of $S$. calantha reach $1-1.5 \mathrm{~cm}$ in diameter.

Paratypes. COLOMBIA. Magdalena: Sierra Nevada de Santa Marta, flanco occidental, Mpio. Ciénaga, 1350 m, 3 Apr. 1960, Romero-Castañeda 8254 (AAU, COL, NY, US); Sierra Nevada de Santa Marta, Quebrada Indiana, 1600 m, 27 Aug. 1972, Kirkbride 1943 (AAU, COL, NY, US), 30 Aug. 1972, Kirkbride 2007 (COL, NY, US); Quebrada Botella, 1700 m, 29 Sep. 1972, Kirkbride 2258 (AAU, NY, US); W of Quebrada Botella along trail to San Pedro de la Sierra, 2000 m, 6 Oct. 1972, Kirkbride 2411 (COL, NY, US); La Gran Vía to San Pedro de la Sierra, 1540 m, 10 May 1983, Escobar \& Santa 3469 (HUA, NY); Alto de Mira, 1100-1500 m, 16 June 1989, Madriñán 334 (MO); Alto de Mirador, Sierra Nevada de Santa Marta, 1200 m, 11 Mar. 1992, Gentry \& Saenz 76256 (MO), Gentry \& Saenz 76288 (MO); Sierra Nevada de Santa Marta, El Campano, transect 10-11, 1700 m, 11 June 1993, Gentry \& Ortiz 79848 (MO). 


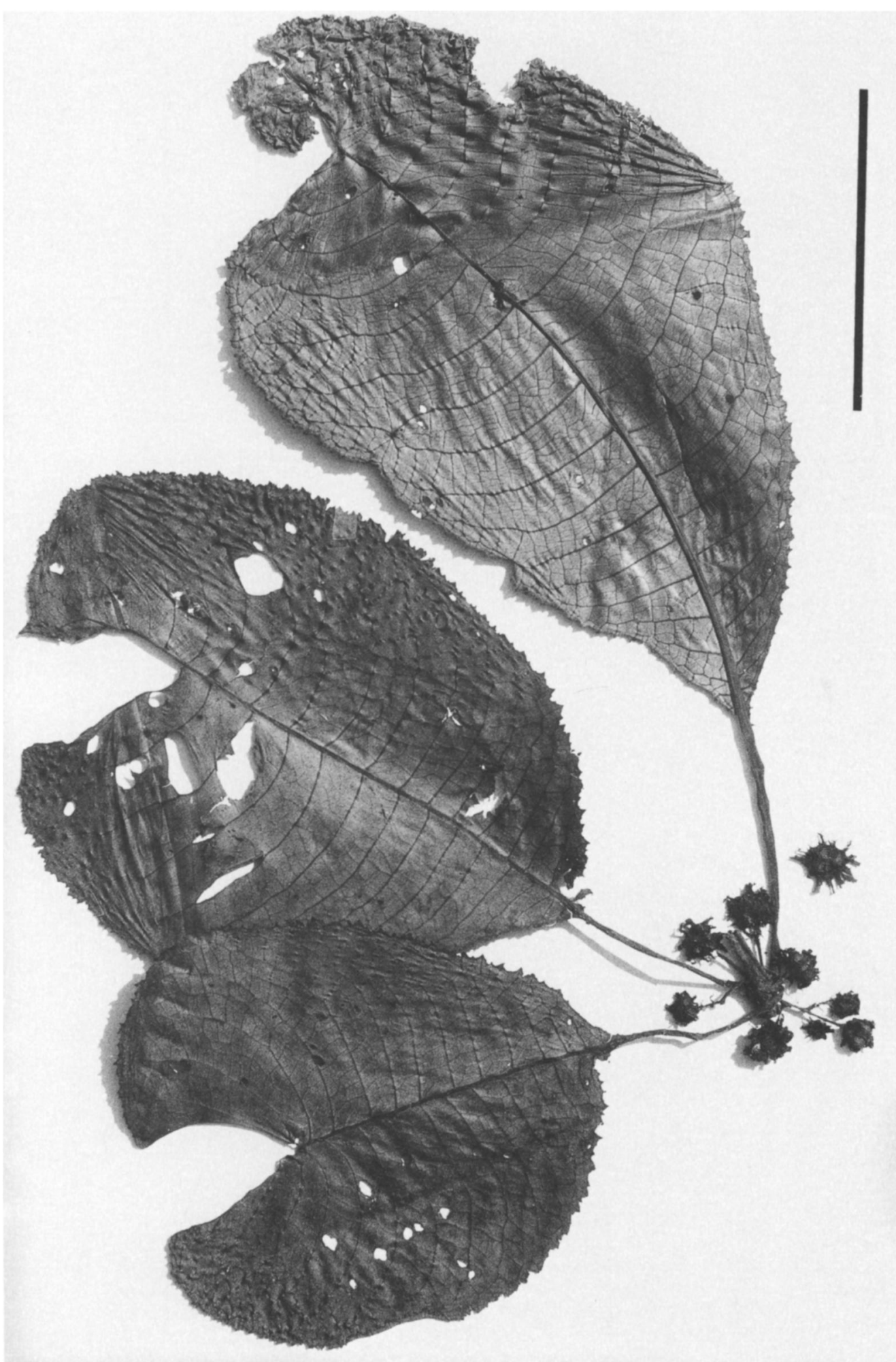

Figure 5. Siparuna calantha (Perkins) Renner \& Hausner (Gentry \& Ortiz 79848, MO, paratype). Fruiting specimen (scale bar equals $10 \mathrm{~cm}$ ). 


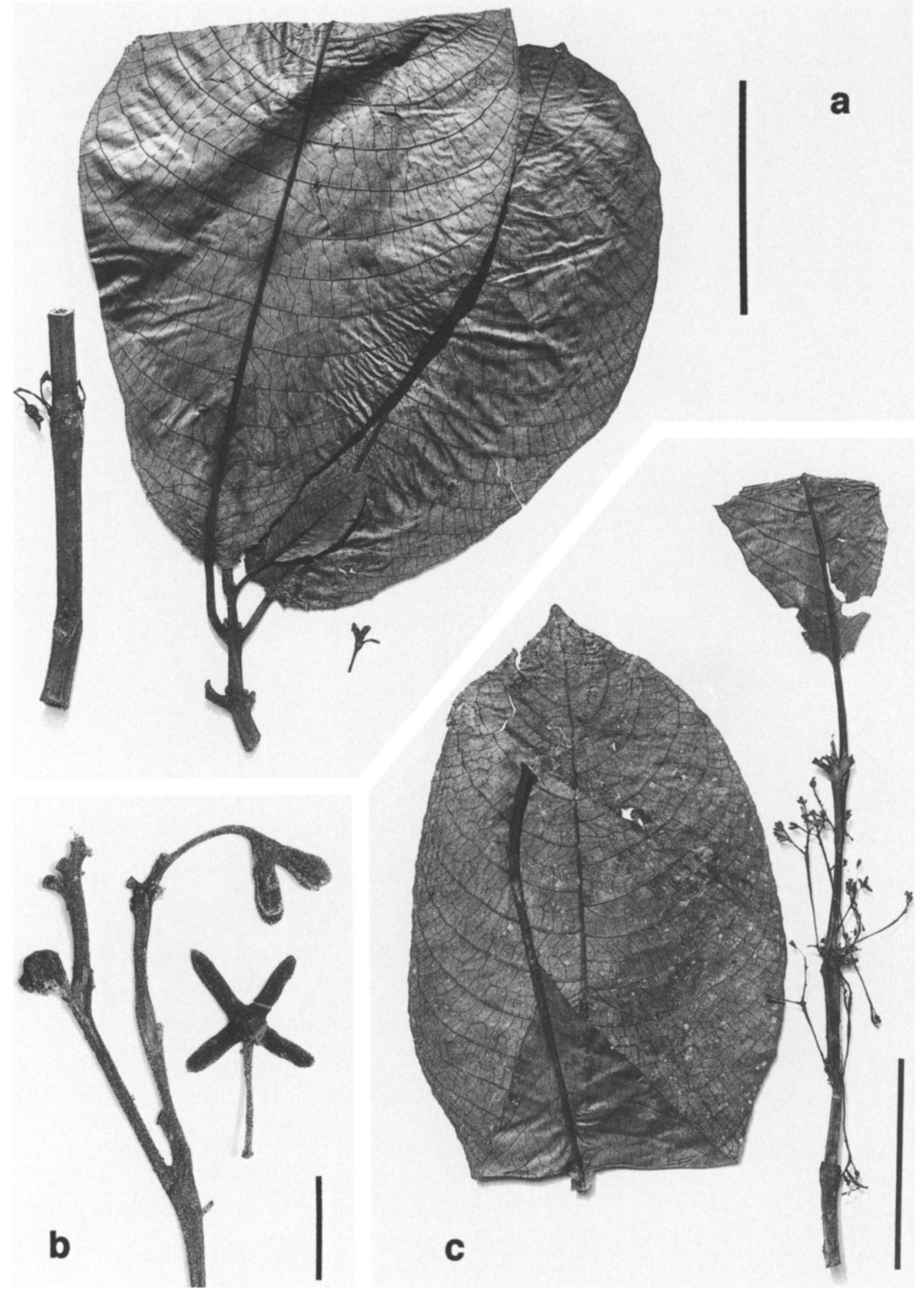

Figure 6. Siparuna vasqueziana Renner \& Hausner. - a. Female specimen (Rojas et al. 0280, MO, paratype; scale bar equals $10 \mathrm{~cm}$ ). - b. Male inflorescence and flower (Vásquez et al. 24278, MO, paratype; scale bar equals $1 \mathrm{~cm}$ ). —. Male specimen (Vásquez et al. 24278, MO; scale bar equals $10 \mathrm{~cm}$ ). 
Siparuna vasqueziana Renner \& Hausner, sp. nov. TYPE: Peru. Amazonas: Distr. El Cenepa, Comunidad de Tutino, Pumpu-entsa, primary forest, $340 \mathrm{~m}$, male, 28 June 1997, R. Vásquez, A. Peña, E. Chávez \& E. Quiaco 24278 (holotype, AMAZ not seen; isotypes, F, HUT not seen, MO, MOL not seen, NY, USM not seen, W) . Figures 3 and 6 .

Differt a Siparuna macrotepala Perkins foliis majoribus $(26-37 \times 17-19 \mathrm{~cm}$ vs. $9-23 \times 5-11 \mathrm{~cm})$, floribus majoribus, tepalis longis $(3-10 \times 1.5-3.5 \mathrm{~mm}$ vs. $0.6-4 \times$ $0.3-0.6 \mathrm{~mm})$.

Dioecious treelet, 4-5 m tall, branchlets distinctly quadrangular, flattened at the nodes, with short, simple or few-branched hairs. Leaves opposite, sometimes unequal in size and petiole length, the petioles $2.5-9.5 \mathrm{~cm}$ long, the lamina drying greenish brown, papery and brittle, broadly obovate, 26$37 \times 17-19 \mathrm{~cm}$, the base obtuse, rounded, or truncate, the apex short-acuminate, both surfaces with scarce short simple, bi-, or trifid hairs, with 16 to 18 pairs of secondary veins, these flat above, distinctly raised below, the margin denticulate, the teeth most pronounced near the blade base. Cymes up to $7.5 \mathrm{~cm}$ long in the male, 3- or 4-branched (Fig. 6c), often on leafless nodes, with 10 to 12 flowers, pubescent like the branchlets. Male floral cup at anthesis $1.3-2.1 \mathrm{~mm}$ diam. and $1.1-1.6 \mathrm{~mm}$ high, subglobose, with short (0.05-0.2 mm long) simple to three-branched whitish hairs, some of these also on the tepal surfaces and margins, the 4 tepals spatulate to oblong (Fig. 6b), 3-10 × 1.5$3.5 \mathrm{~mm}$, fresh yellowish, the floral roof moderately raised, glabrous; stamens 22 to 24 . Female flowers at anthesis similar to male flowers, the floral cup $3.3-3.7 \mathrm{~mm}$ diam. and 3-3.5 $\mathrm{mm}$ high, the floral roof tightly surrounding the styles; styles 15 to 20 Receptacle in young fruits smooth (Vásquez et al. 22423), mature fruits unknown.

Distribution (Fig. 3), habitat, and phenology. Siparuna vasqueziana currently appears to be restricted to Peruvian Amazonian primary forests at elevations of up to $400 \mathrm{~m}$.

Etymology. The species is named to honor it: collector, Rodolfo Vásquez, curator of Peruvian material at the Missouri Botanical Garden and author of the first comprehensive florula for the Peruvian Amazonian lowlands (Vásquez Martínez, 1997).

Siparuna vasqueziana has much longer tepals than any other species of Siparuna known. Among Ecuadorean and Peruvian species, it is further distinct by its combination of strongly quadrangular branchlets and large smooth (not bullate) leaves. Similar quadrangular branches are seen only in $S$. macrotepala, but that species has smaller leaves and much shorter tepals (cf. the Latin diagnosis above, which contrasts the two species in terms of leaf size and tepal length).

Paratypes. PERU. Amazonas: Distr. El Cenepa, Comunidad de Mamayaque, 400 m, 11 Aug. 1997, Rojas 0280 (F, MO, NY, US, W); Distr. El Cenepa, Comunidad de Mamayaque, Río Cenepa, Quebrada Sáasa, 400 m, 6 Feb. 1997, Vásquez et al. 22423 (AMAZ, F, HUT not seen, MO, MOL not seen, NY, USM not seen, W). Loreto: Distr. Las Amazonas, Explornapo camp, 140 m, 6 Jan. 1993, Vásquez 18285 (MO).

Acknowledgments. We thank José Luís Fernández Alonso (COL), Ricardo Callejas (HUA), and curators of the smaller Colombian herbaria cited in this paper's introduction for gracious permission to study Siparuna material in their care. Barbara Alongi is thanked for the two drawings and Santiago Madriñán (Universidad de Los Andes, Bogotá) for being a wonderful host during SR's visits to Bogotá.

\section{Literature Cited}

Feil, J. P. 1992. Reproductive ecology of dioecious Siparuna (Monimiaceae) in Ecuador-A case of gall midge pollination. Bot. J. Linn. Soc. 110: 171-203.

Renner, S. S. 1999. Circumscription and phylogeny of the Laurales: Evidence from molecular and morphological data. Amer. J. Bot. 86: 1301-1315.

\& A. Chanderbali. In press. What is the relationship between Hernandiaceae, Lauraceae, and Monimiaceae, and why is this question so difficult to answer? Int. J. Plant Sci.

\& G. Hausner. 1995. New Species of Siparuna (Monimiaceae) I. Four new species from Ecuador and Colombia. Novon 5: 61-70.

$\rightarrow \longrightarrow \&-1996$. New Species of Siparuna (Monimiaceae) II. Seven new species from Ecuador and Colombia. Novon 6: 103-116.

\& -1997 . Siparunaceae, Monimiaceae. In G. Harling \& L. Andersson (editors), Flora of Ecuador 59: $1-125$.

- A. E. Schwarzbach \& L. Lohmann. 1997. Phylogenetic position and floral function of Siparuna (Siparunaceae: Laurales). Int. J. Pl. Sci. 158(6 suppl.): S89-98.

Vásquez Martínez, R. 1997. Flórula de las Reservas Biológicas de Iquitos, Peru. Monogr. Syst. Bot. Missouri Bot. Gard. 63: 1-1046. 